\title{
$\mathrm{Fe}-\mathrm{Si}$ 合金の繰り返し変形に伴う転位組織の形成機構
}

\author{
首藤洋志1,2,* 小野寺暁理 $2, *$ 荒井重勇 ${ }^{3} \quad$ 宮 澤 知 孝 ${ }^{2} \quad$ 藤 居 俊 $之^{2}$
}

\author{
1新日鐵住金株式会社技術開発本部 \\ 2 東京工業大学物質理工学院 \\ 3名古屋大学未来材料・システム研究所 \\ J. Japan Inst. Met. Mater. Vol. 82, No. 5 (2018), pp. 176-181 \\ (C) 2018 The Japan Institute of Metals and Materials
}

\section{Formation Mechanism of Dislocation Structures during Cyclic Deformation in an Fe-Si Alloy}

\author{
Hiroshi Shuto $^{1,2, *}$, Akari Onodera ${ }^{2, *}$, Shigeo Arai $^{3}$, Tomotaka Miyazawa ${ }^{2}$ and Toshiyuki Fujii ${ }^{2}$ \\ ${ }^{1} R$ \& D Laboratories, Nippon Steel \& Sumitomo Metal Corporation, Oita 870-0992 \\ ${ }^{2}$ School of Materials and Chemical Technology, Tokyo Institute of Technology, Tokyo 152-8552 \\ ${ }^{3}$ Institute of Materials and Systems for Sustainability, Nagoya University, Nagoya 464-8603
}

\begin{abstract}
The dislocation structures in polycrystalline $\mathrm{Fe}-1$ mass $\% \mathrm{Si}$ after cyclic deformation were observed using high voltage electron microscopy in order to investigate the formation mechanism of the dislocation structures. Vein, wall, and cell structures were found in a deformed specimen. Detailed orientation and structure of the walls were analyzed. Burgers vectors of dislocations in the walls were $a / 2[111]$ and $a / 2[\overline{1} 11]$. A set of walls was arranged parallel to the (110) plane and it was found to be a part of labyrinth structure consisting of the (110) and (001) walls. It is suggested that the formation mechanism of the labyrinth structure in bcc metal is reasonably understood by extending the mechanisms in fcc metals. [doi:10.2320/jinstmet.JBW201711]
\end{abstract}

(Received January 15, 2018; Accepted February 23, 2018; Published March 30, 2018)

Keywords: fatigue, cyclic deformation, dislocation structure, wall structure, labyrinth structure, iron, steel, silicon, high voltage electron microscopy

\section{1. 緒言}

著者らはこれまで, 疲労特性と疲労試験によって形成され る転位組織に相関があることを示してきた1,2). Yokoi らは, 疲労特性の良好な $\mathrm{Cu}$ 添加鋼において, 低サイクル疲労試験 後の転位組織が Cell 組織ではなくVein 組織であることを報 告した ${ }^{1)}$. Shuto らは IF 鋼中の固溶元素を変化させ, Cell 組 織を形成しやすい $\mathrm{Fe}-\mathrm{Ni} よ り も \mathrm{Cell}$ 組織を形成しにくい $\mathrm{Fe}-\mathrm{Si}, \mathrm{Fe}-\mathrm{Al}, \mathrm{Fe}-\mathrm{Cu}$ の方が疲労特性は優れていると報告し た $^{2)}$.これらの知見から, 鋼の疲労による転位組織形成を制 御し, Cell 組織の形成を抑制できれば，鋼板の疲労特性は向 上することが期待できる.

疲労に伴う転位組織を制御するには, その形成過程を明ら かにすることが重要である. fcc 金属においては, すべり系が $\{111\}<110>$ に特定されるため, 活動すべり系と形成される転 位組織との関係が議論しやすく, これまでの研究によって, Vein 組織, Wall 組織, Labyrinth 組織, Cell 組織などの形成 過程がまとめられている ${ }^{3-7)}$. 一方で, 鉄に代表される bcc 金 属ではその理解は不十分で, 例えば Labyrinth 組織を構成す る転位 Wall の方位の解釈は一致していない ${ }^{8-13)}$.

Mori らは Fe-3 mass\% Si 合金単結晶に対して単一すべり

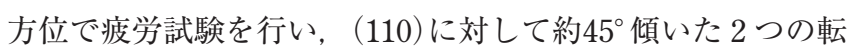

\footnotetext{
* 東京工業大学大学院生 (Graduate Student, Tokyo Institute of Technology)
}

位 Wall が形成されることを報告した ${ }^{8)}$. Mori らはこれを “Extended Cell”と呼んだが, その転位Wallの結晶学的な方位 は同定しておらず，形成過程についても不明としている. Fielding らは Fe-25 mass\% Cr 合金多結晶に対して疲労試験 を行い, 応力軸が $[10 \overline{1}]$ となる結晶粒に着目し， 2 種類の転 位Wall からなる Labyrinth 組織が形成されると報告した ${ }^{9)}$ 。 2 種類の転位 Wall のうち一方は(101)Wall であると報告したが, 他方については記載が無く, 形成過程は議論していない. Turenne らはbcc 金属の繰り返し変形によって形成される Labyrinth 組織における転位 Wall の方位を幾何学的に予測す ることを試みている ${ }^{10)}$. 具体的には, 活動するすべり系を 2 つ選択し，それぞれのすべり系において刃状転位の双極子 ループを考え, 2 種類の転位ループの幾何学的配列を議論し た. その結果, 一つのすべり系の組み合わせに対し， 3 通り の転位 Wall の形成方位 (転位 Wall が平行となる面)を予測し, そのうち, 構造が安定な二つが選択され, Labyrinth 組織を構 成する転位Wall になるとしている。 そして, これまでの実験 結果 ${ }^{8,9)}$ との比較を行い, 予測とよい一致を示すと述べた。し かし, 議論の過程では, 強引な推論も見受けられ, 実験結果 を全て説明しているとは言いがたい. Roven らは低炭素鋼で, 塑性ひずみ振幅一定の疲労試験を行い, 塑性ひずみ振幅 $3.6 \times$ $10^{-3}$ および $4.1 \times 10^{-3}$ で Labyrinth 組織ができると報告したが, 転位Wall の形成方位には言及していない11,12). Petrenec らは フェライト系ステンレス鋼で疲労試験を行い, 2 つすすへり 系が同時に活動しやすい結晶粒で Labyrinth 組織を観察して 
いる13). fcc 金属のとき7) と同様, Labyrinth 組織を構成する 2 種類の転位 Wall のうち一方は, 活動する 2 種類の転位の バーガースベクトルの二等分面になると述べているが，もう 一方の転位Wall の方位には言及していない.

このように, bcc 金属中に Labyrinth 組織が形成されること はしばしば報告されてきたが，その形成方位と形成過程の議 論は十分とは言いがたい。そこで，本研究ではbcc 構造を持 つ $\mathrm{Fe}-1 \mathrm{mass} \% \mathrm{Si}$ 合金多結晶の繰り返し変形によって形成さ れる転位組織を超高圧電子顕微鏡により詳細に観察し, 転位 組織の形成過程を明らかにすることを目的とする.

\section{2. 実 験 方 法}

\section{1 供試材}

Wall 組織や Labyrinth 組織の形成が報告されている $\mathrm{Fe}-1$ mass \% Si 合金を準備した ${ }^{14)}$ ，化学成分を Table 1 に示す。圧 延および熱処理は Fig. 1 に示す手順によって実施した。粗圧 延，仕上圧延により板厚 $5 \mathrm{~mm}$ とした後， $700^{\circ} \mathrm{C}, 60 \mathrm{~min}$ の 熱処理を 2 回行い, 疲労特性に影響を及ぼす固溶 $\mathrm{C}$, 固溶 $\mathrm{N}$ を TiC, TiNとして析出させた。得られた供試材の組織写真 を Fig. 2 に示す。供試材はフェライト組織であり, 平均結晶 粒径は $33 \mu \mathrm{m}$ であった。供試材に対し, 圧延方向に垂直な方 向を引張方向として, 引張試験を行った結果を Fig. 3 に示す. $0.2 \%$ 耐力は $174 \mathrm{MPa}$, 引張強さは $382 \mathrm{MPa}$ であった。また, 応力ーひずみ曲線は不連続降伏を示したことから, 固溶 Cや

Table 1 Chemical composition of sample.

\begin{tabular}{ccccccccc}
\hline $\mathrm{Fe}$ & $\mathrm{C}$ & $\mathrm{Si}$ & $\mathrm{Mn}$ & $\mathrm{P}$ & $\mathrm{S}$ & $\mathrm{Al}$ & $\mathrm{Ti}$ & $\mathrm{N}$ \\
\hline \hline bal. & 0.0024 & 0.96 & $<0.003$ & 0.01 & $<0.003$ & 0.027 & 0.035 & 0.0021 \\
\hline
\end{tabular}

\section{$1100^{\circ} \mathrm{C}, 60 \mathrm{~min} \quad 1100^{\circ} \mathrm{C}, 60 \mathrm{~min}$}

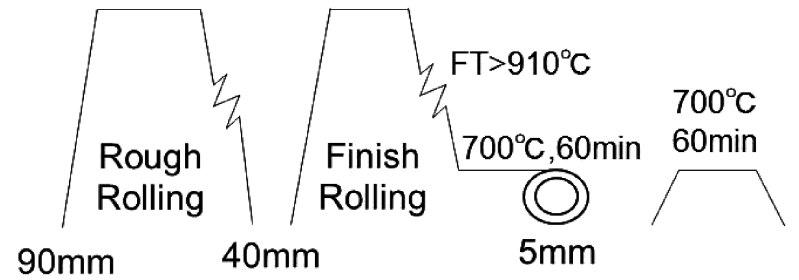

Fig. 1 Hot-rolling and annealing process.

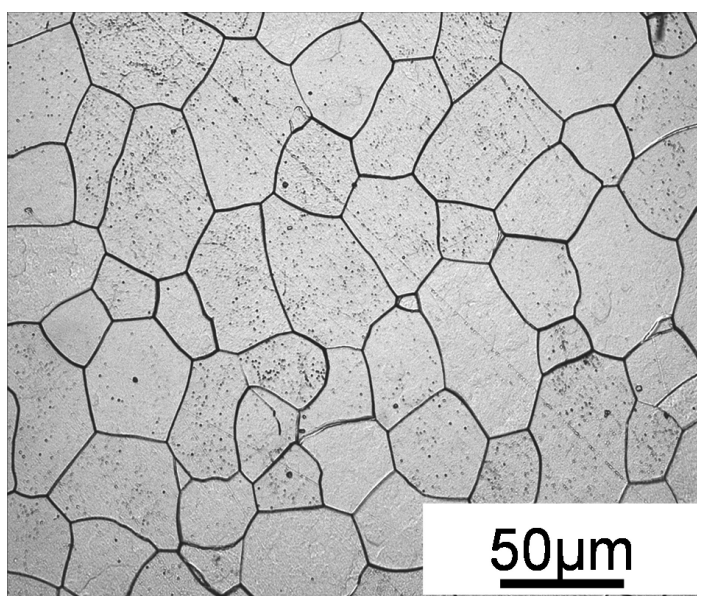

Fig. 2 Microstructure of sample.
固溶 Nの転位運動への影響は無視できる.

\section{2 疲労試験条件}

仕上圧延後の板厚 $5 \mathrm{~mm}$ の供試材に対し, 表裏を $0.5 \mathrm{~mm}$ ずつ機械研磨して板厚 $4 \mathrm{~mm}$ とした. さらに電解研磨を行い, 表層の加工層を除去した後，圧延方向に垂直な方向を長手方 向として, Fig. 4 に示す疲労試験片を作製した。得られた試 験片に対し，電気式油圧制御疲労試験装置(MTS 社製318.1) を用いて, 室温大気圧下で全ひずみ振幅一定の引張 - 圧縮疲 労試験を行った。疲労試験条件は, ゲージ長さ $8 \mathrm{~mm}$, 全ひ ずみ振幅 $5 \times 10^{-3}$, ひずみ速度 $4 \times 10^{-4} \mathrm{~s}^{-1}$, 応力比 $R=-1$ とし た.ひずみは試験片の平行部に取り付けた伸び計で測定した.

\section{3 転位組織観察手法}

疲労試験後の試験片の平行部から, 転位組織観察用の薄膜 を採取した。まず平行部から薄膜の板厚方向が試験片の幅方 向と一致するように幅 $5 \mathrm{~mm}$, 長さ $10 \mathrm{~mm}$, 厚さ $1 \mathrm{~mm}$ の試 料を切り出し, 厚さ $100 \mu \mathrm{m}$ まで機械研磨を行った。 その後, 直径 $3 \mathrm{~mm}$ に打ち抜き, 電解研磨によりさらに板厚を薄くし た. 電解研磨には過塩素酸とメタノールの容積比が $1: 9 の$ 電解

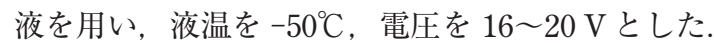

作製した薄膜に対し，超高圧電子顕微鏡 $(J E M-1000 \mathrm{~K} R \mathrm{R})$ を用いて，加速電圧 $1000 \mathrm{kV}$ で転位組織の観察を行った。本 装置は加速電圧が高い上に走査透過電子顕微鏡 $(\mathrm{STEM})$ 機能 を有するため, 広い視野において，等厚干渉縞やベンドコン ターの無い転位組織を観察することが可能である。試料ホル ダーには二軸傾斜ホルダーを用い, 傾斜により回折ベクトル $\mathrm{g}$ を変化させることで転位のバーガースベクトルを同定した

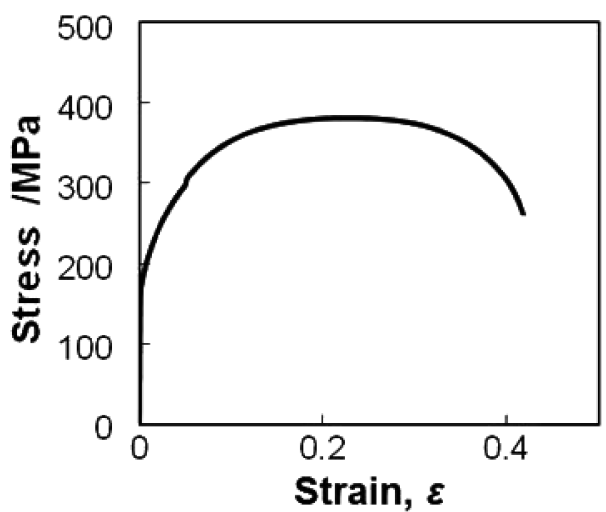

Fig. 3 Stress-strain curve and mechanical properties of sample.

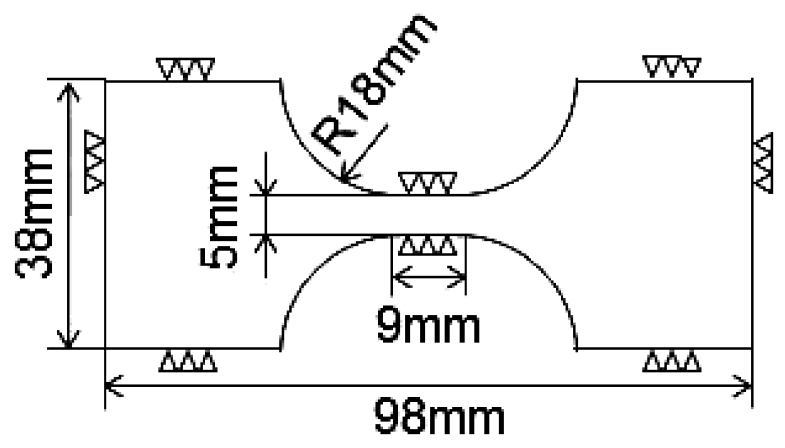

Fig. 4 Shape and size of fatigue test specimen. 
観察は主にSTEM モードの明視野条件で行った。

\section{3. 結果}

\section{1 疲労試験}

Fig. 5 に繰り返し回数と応力振幅の関係を示す。全ひずみ 振幅一定条件の元で，供試材は 10 cycle までに急激に繰り返 し硬化し, 10 cycle 以降もその程度は小さくなるものの繰り 返し硬化を示した。Fig. 6 に繰り返し回数と塑性ひずみ振幅 の関係を示す. 1 cycle から 10 cycle までの間に塑性ひずみ振 幅は $3.8 \times 10^{-3}$ から $3.3 \times 10^{-3}$ まで低下し，その後 1000 cycleま でほぼ一定の值を示した。ささらに，2000 cycle 以降に塑性ひ ずみ振幅は低下し, 破断に至った.

これまでにフェライト合金で Labyrinth 組織が観察されて いる塑性ひずみ振幅は $2.0 \times 10^{-3} \sim 4.1 \times 10^{-3}$ であり ${ }^{8,9,11,12)}$ ，本 研究において塑性ひずみ振幅が安定した領域の值に近い。今 回，塑性ひずみ振幅は 10 cycle から 1000 cycle にかけてほぼ 一定值を示しており，1000 cycle の時点でその塑性ひずみ振 幅に対応した転位組織が発達していると解釈して, 疲労試験 を中断し，薄膜を切り出して転位組織の観察を行った.

\section{2 転位組織観察}

1000 cycle 繰り返し変形後の転位組織を Fig. 7 に示す．供

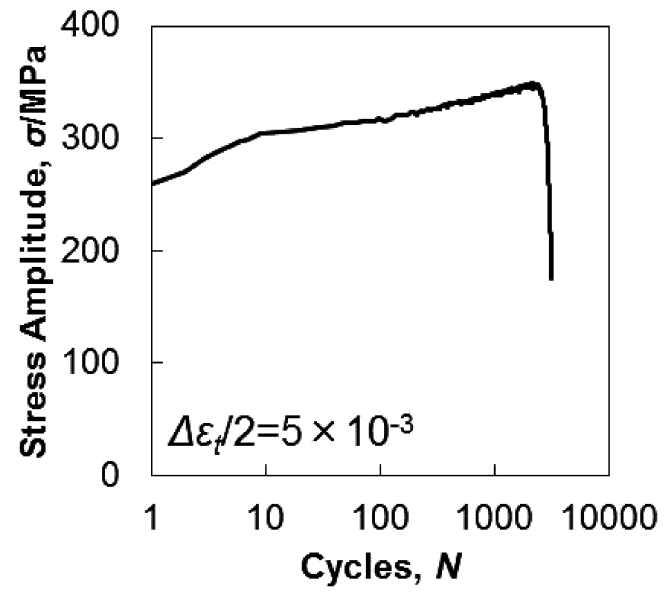

Fig. 5 Cyclic hardening curve for $\mathrm{Fe}-1$ mass $\% \mathrm{Si}$ in constant total plastic strain amplitude cycling.

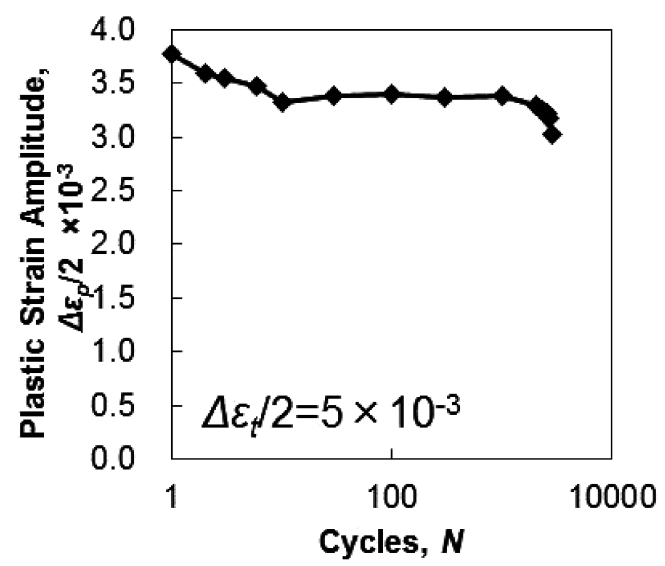

Fig. 6 Plastic strain amplitude of $\mathrm{Fe}-1$ mass $\% \mathrm{Si}$ in constant total plastic strain amplitude cycling.
試材の転位組織は同一結晶粒内でも均一ではなく，領域ごと に Vein 組織，Wall 組織，Cell 組織と異なる組織が形成されて いた．本研究ではTurenneらが提唱した仮説を検証するため, Wall 組織に着目して詳細に観察を行った。

Fig. 8 に, Wall組織が形成された同一視野を, [001] 方向か ら 3 種の異なる回折条件で観察した STEM 明視野像, および この視野に対応するステレオ投影図を示す。本合金における 転位のバーガースベクトル b は $<111>$ 方向に平行であるため, Fig. 8(a)の回折条件では $\mathbf{g} \cdot \mathbf{b} \neq 0$ となり, 観察視野内に存 在する全ての転位が観察可能である．Fig. 8(a)より，Wall 組 織は転位が周期的に集積した転位 Wall と転位密度が小さい Channel で構成されており, 転位 Wall 間の距離は $0.7 \mu \mathrm{m}$ 程 度であった。これはUshioda らが $\mathrm{Fe}-1$ mass\% $\mathrm{Si}$ 合金において 応力振幅 $381 \mathrm{MPa}$ の疲労試験で報告した值とほぼ一致する ${ }^{14)}$. また，転位 Wall は Fig. 8(a)の右上から左下に向かって平行 に配列しており，これは Fig. 8(d)のステレオ投影図より，

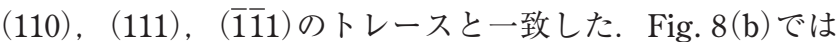
$\mathbf{b}=a / 2[\overline{1} 11]$ または $\mathbf{b}=a / 2[1 \overline{1} 1]$ のときに $\mathbf{g} \cdot \mathbf{b}=0$ を満たす ため，該当する転位のコントラストが消滅する．Fig. 8(a) と （b）を比較すると，コントラストが消滅した転位は確認でき ないため，このWall組織内に $\mathbf{b}=a / 2[\overline{1} 11]$ または $\mathbf{b}=a / 2[1 \overline{1} 1]$ を持つ転位は含まれていないことが分かった．Fig. 8(c)では $\mathbf{b}=a / 2[111]$ または $\mathbf{b}=a / 2[\overline{1} \overline{1} 1]$ のときに $\mathbf{g} \cdot \mathbf{b}=0$ を満たし， 該当する転位のコントラストが消滅する. Fig. 8(a) と (c) を比 較すると, 転位 Wall 中の転位と Channel 内の転位の両方のコ ントラストが弱くなっていた。このことから，今回観察され た転位 Wall は $\mathbf{b}=a / 2[111]$ もしく $\mathbf{b}=a / 2[\overline{1} \overline{1} 1]$ の転位のう ちの片方もしくは両方によって形成されていることが分かっ た.

4. 考察

転位 Wall の形成方位を明らかにするため，まず転位 Wall を構成する転位のバーガースベクトルが何種類あるかを考え る、単一すべりの活動によって形成される Ladder 組織に見 られる転位 Wall は，主すべり系の刃状転位双極子で構成され

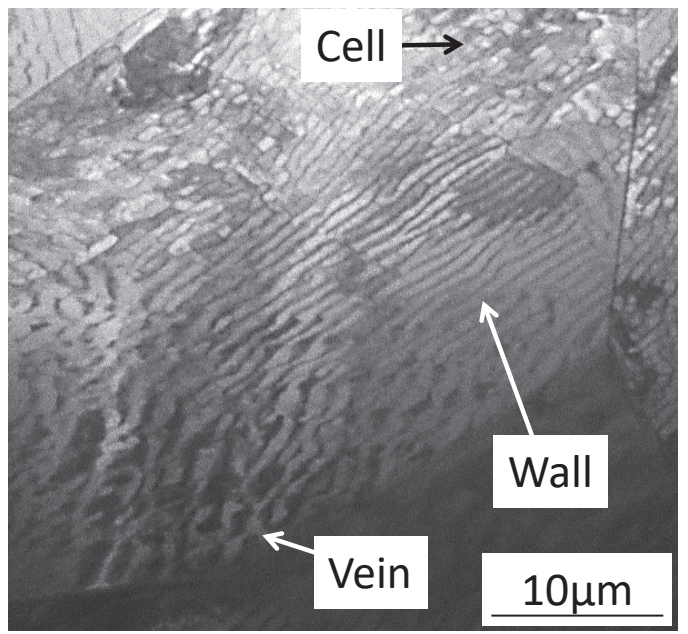

Fig. 7 Representative dislocation structures after 1000 cycles of constant strain amplitude cycling. 

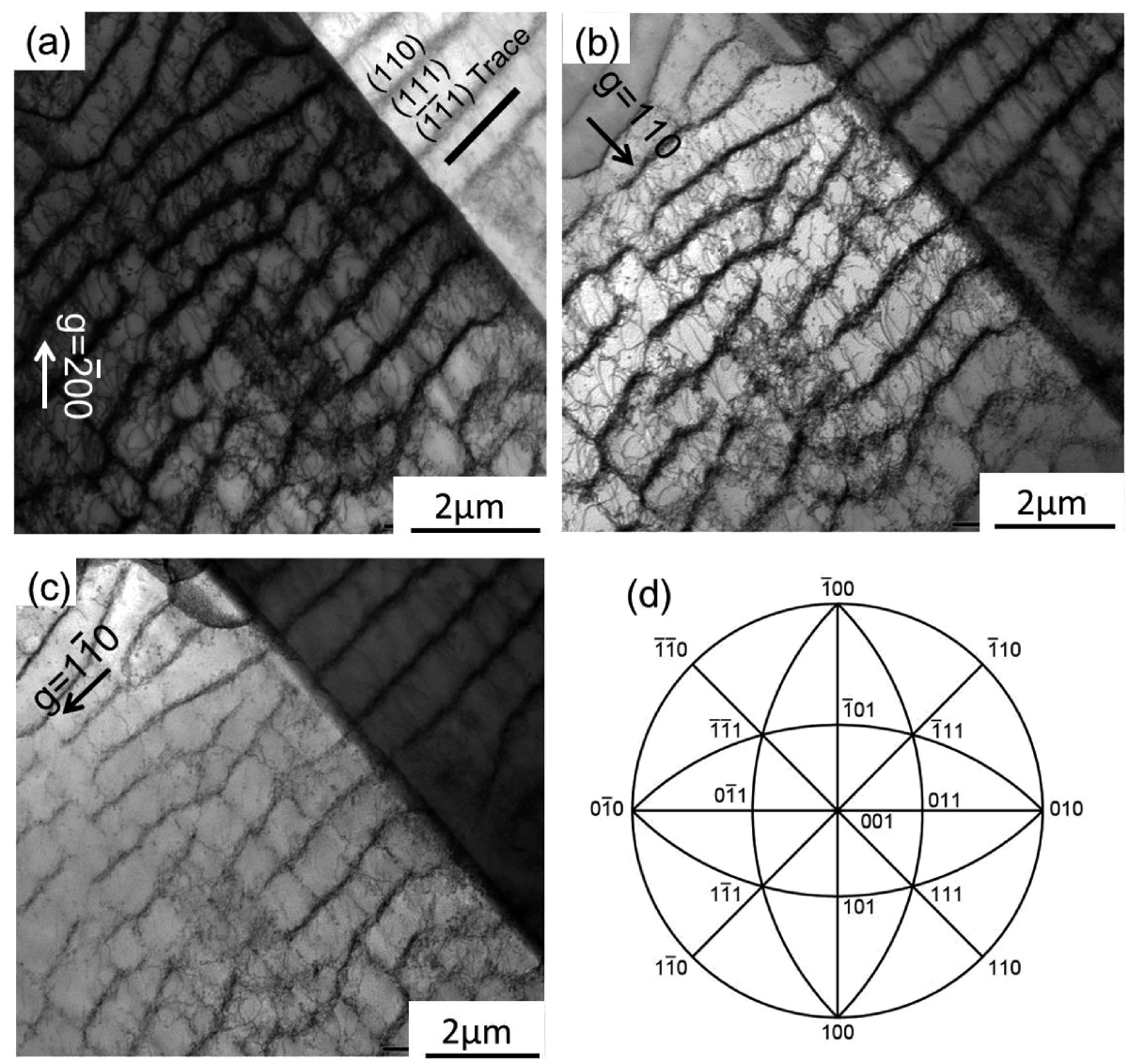

Fig. 8 STEM images of wall structures in a grain oriented to [001] observed with various $\mathbf{g}$ conditions. (a) $\mathbf{g}=\overline{2} 00$. All of dislocations are visible. (b) $\mathbf{g}=110$. All of dislocations are visible. (c) $\mathrm{g}=1 \overline{1} \mathbf{1}$. Contract of dislocations are decreased. (d) Stereo projection.

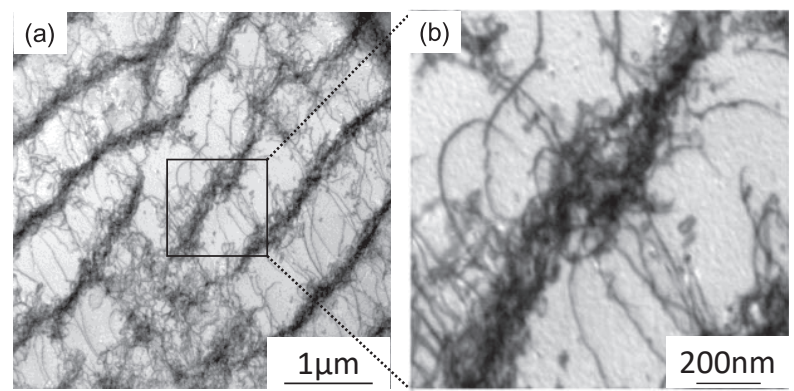

Fig. 9 Details of the wall structures. Walls are nearly edge-on.

ている7). よって, 単一のバーガースベクトルの転位で構成 される転位 Wall の法線の方向は，そのバーガースベクトルの 方向と一致する。このことは Turenneらの幾何学的な推測か らも求められる ${ }^{10)}$ 。この考えに従えば, 転位 Wall を構成する 転位のバーガースベクトルが $\mathbf{b}=a / 2[111]$ のみであると仮定 した場合, 転位 Wall は [111] に垂直な(111)Wall となる。実 際に Fig. 8(a)から，転位 Wall の方位は (111)トレースと一致 している.しかし，Fig. 8(d)のステレオ投影図から分かるよ うに，観察した転位 Wall が(111)Wall ならば, 観察面に対し edge-onの条件にはならず, $35^{\circ}$ 傾斜して観察されることにな る. EELSによる測定から薄膜の厚さは約 $500 \mathrm{~nm}$ であったこ とから, 転位 Wall が $35^{\circ}$ 傾斜している場合には, 少なくとも $300 \mathrm{~nm}$ 程度の厚さを持つ転位 Wall として観察されるはずで ある. Fig. 9 にWall 組織の拡大写真を示すが, 転位Wall の厚 さは薄い部分で $100 \mathrm{~nm}$ 程度であり, $35^{\circ}$ 傾斜した転位Wall と
は考えにくい.よって,ここで観察した転位 Wall は b= $a / 2[111]$ の転位のみで構成される (111)Wall とはいえない。転 位 Wall 中の転位のバーガースベクトルが $\mathbf{b}=a / 2[\overline{1} 11]$ のみと 仮定した場合にも同様の考察から，(六1)Wall と解釈すると 矛盾が生じる，以上の考察から，転位Wall 中には， b= $a / 2[111]$ および $\mathbf{b}=a / 2[\overline{1} \overline{1} 1]$ の 2 種類の転位が存在すると解 釈する方が合理的である.

次に，転位 Wall の形成方位を考察する．Turenne らによれ ば，活動する 2 種類のすべり系において，刃状転位の双極子 ループを考え，その 2 種類の双極子ループの幾何学的配列か ら転位Wall の形成方位が 3 通りに決まる10)。さらに，それぞ れの転位 Wall と， 2 種類のすべり系のバーガースベクトルの なす角度 (Sweeping Angle)を計算し, Sweeping Angle が90 に近いほど双極子ループが転位 Wall に積層しやすく, 安定な 構造になるとした ${ }^{10)}$ 。この解釈に基づき，転位Wall を構成す る転位のバーガースベクトルが $\mathbf{b}=a / 2[111]$ および $\mathbf{b}=$ $a / 2[\overline{1} \overline{1} 1]$ の 2 種類である場合の転位Wall の形成方位と Sweeping Angle を求め, Table 2 にまとめた.ずへり面は $\{110\}$ を 仮定した，例えば，活動するすべり系が(101) [111] と (101) [1̄11] の場合には，転位 Wall が平行になる面として (001),

(120)，（120)の 3 種類が予測される。このとき，それぞれの Sweeping Angle が $35^{\circ}$ ， 15，51 となり， Sweeping Angle が 大きい(001)Wall と (120)Wall が選択されると解釈できる. な お, Turenne らは，活動するすべり面が共有されている場合 に形成される (001) Wallの Sweeping Angle を0としているが, 
Table 2 Wall orientations in Labyrinth structure predicted from Ref. 10). $\alpha, \beta$ and $\gamma$ correspond to sweeping angles of Wall A, Wall B and Wall C respectively.

\begin{tabular}{|c|c|c|c|c|c|c|c|c|c|c|c|}
\hline \multirow{2}{*}{$\begin{array}{l}\text { Angles between } \\
\text { slip planes / deg. }\end{array}$} & \multirow{2}{*}{$\begin{array}{c}\text { Primary slip } \\
\text { system }\end{array}$} & \multirow{2}{*}{$\begin{array}{c}\text { Secondary slip } \\
\text { system }\end{array}$} & \multicolumn{3}{|c|}{ Wall orientation } & \multicolumn{6}{|c|}{ Sweeping angles / deg. } \\
\hline & & & A & B & c & $\alpha_{1}$ & $\alpha_{2}$ & $\beta_{1}$ & $\beta_{2}$ & $\gamma$ & \\
\hline $\begin{array}{l}90 \\
90\end{array}$ & $\begin{array}{l}\left(\begin{array}{lll}1 & 0 & 1\end{array}\right)\left[\begin{array}{lll}1 & 1 & 1 \\
0 & 1 & 1\end{array}\right)\left[\begin{array}{lll}1 & 1 & 1\end{array}\right]\end{array}$ & $\left.\begin{array}{l}\left(\begin{array}{lll}1 & 0 & 1\end{array}\right)\left[\begin{array}{lll}1 & \overline{1} & 1\end{array}\right] \\
\left(\begin{array}{lll}0 & 1 & 1\end{array}\right)\left[\begin{array}{lll}1 & 1 & 1\end{array}\right]\end{array}\right]$ & $\left.\begin{array}{l}\left(\begin{array}{lll}0 & 0 & 1\end{array}\right) \\
\left(\begin{array}{lll}0 & 0 & 1\end{array}\right)\end{array}\right)$ & 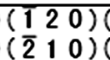 & $\begin{array}{l}\left(\begin{array}{lll}1 & 2 & 0\end{array}\right) \\
\left(\begin{array}{lll}1 & 2 & 0\end{array}\right)\end{array}$ & $\begin{array}{l}35 \\
35\end{array}$ & $\begin{array}{l}35 \\
35\end{array}$ & $\begin{array}{l}15 \\
15\end{array}$ & $\begin{array}{l}15 \\
15\end{array}$ & $\begin{array}{l}51 \\
51\end{array}$ & $\begin{array}{l}51 \\
51\end{array}$ \\
\hline 0 & & & $(1$ & & & 55 & 55 & 35 & 35 & 0 & 0 \\
\hline 60 & & $(0$ & & & & 55 & 55 & 14 & 14 & 31 & 31 \\
\hline 60 & 11 & $\left(\begin{array}{lll}1 & 1 & 0\end{array}\right)\left[\begin{array}{ll}1 \\
1\end{array}\right.$ & (c & (3) & & 47 & 21 & 38 & 18 & 17 & 61 \\
\hline 60 & 11 & $\left(\begin{array}{lll}\overline{1} & 1 & 0\end{array}\right)\left[\begin{array}{ll}\overline{1} & \overline{1}\end{array}\right.$ & $(\overline{1} 2$ & $(3$ & $(\overline{1} \overline{5}$ & 38 & 18 & 47 & 21 & 17 & 61 \\
\hline 60 & & $(10)$ & $(\overline{2}$ & & & 18 & 38 & 21 & 47 & 61 & 17 \\
\hline 60 & ( & $(10$ & $(1$ & $(\overline{3}$ & & 55 & 55 & 14 & 14 & 31 & 31 \\
\hline 60 & $(1$ & $(0$ & & & & 18 & 38 & 21 & 47 & 61 & 17 \\
\hline 00 & 11 & $\left(\begin{array}{llll}0 & 1 & 1\end{array}\right)[$ & & & & 21 & 47 & 18 & 38 & 61 & 17 \\
\hline
\end{tabular}

これは正しくは $35^{\circ}$ であり, Table 2 で修正している. Table 2 に示した形成が予測される転位Wall のうち, 今回観察された 転位 Wall の面方位に近く， かつ観察面に対して edge-onに 近いものは，(110)Wall と (120)Wallのみであった. 2 種類の トレースを, Wall 組織の観察像と合わせて Fig. 10 に示す. Fig. 10 より, 転位 Wall は一部(120)トレースと一致する部分 はあるが，全体として(110)トレースとよく合うことが分か る. Table 2 より (110)Wall が形成されうるすべり系の組み合

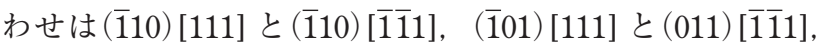

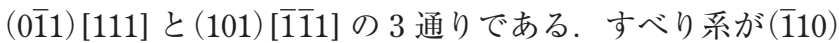

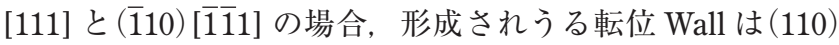
Wall と (001)Wall であるが，（001）Wall は観察面と平行とな り，薄膜を切り出した部分が隣り合う (001)Wallの間のChannel 部分に相当すると考えれば, (001)Wall は観察されず,

(110)Wall のみが観察されたと説明できる。一方で，すべり

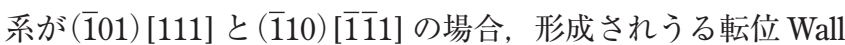
は (110)Wall と (113)Wall である。(113)Wall は観察面と約 $25^{\circ}$ の角度をなすため, もし存在すれば, 観察視野内に少なくと も $1 \mu \mathrm{m}$ 程度の厚さを持つ転位 Wall として観察されるはずで ある。しかし，Fig. 10 にはそれに該当する組織が見られない ため，(113)Wall は形成されていないといえる，また，すべ り系が $(0 \overline{1} 1)$ [111] と (101) [ $\overline{1} \overline{1} 1]$ の場合, 形成されうる転位

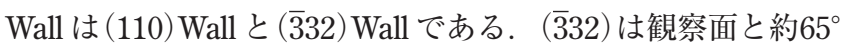
の角度をなすため, 視野内に転位 Wall として観察されるはず

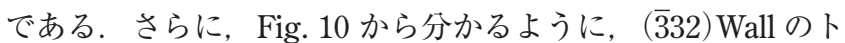
レースは観察視野の左上から右下に向かって平行に配列する. このような特徵に該当する転位 Wall は観察されなかったた め, (332)Wall は形成されていないといえる. 以上の検討か ら, 今回観察された転位組織は (110)Wall と (001)Wall で構成 される Labyrinth 組織を [001] 方向から観察したものと推測さ れる。過去にこのような方位の Labyrinth の報告例はないも のの, Turenne らの説から予測できる転位 Wall の形成方位で ある。ただし，Turenneらの仮説を当てはめるには，主すべ り面と 2 次すべり面が同一である必要があるが，本研究では すべり面の同定を行っていないため，この部分においては更 なる検討の必要がある。 なお， $\{110\}$ に加えて $\{112\}$ もすべり 面の候補として検討したところ，同様の考察から (110)Wallが 形成される余地があることから，すべり面の特定は今後の必 須の課題といえる

本研究で観察された (110)Wall と (001)Wallによる Labyrinth 組織は, f f c 金属における $\mathrm{Li}$ らの解釈を用いても説明が可能

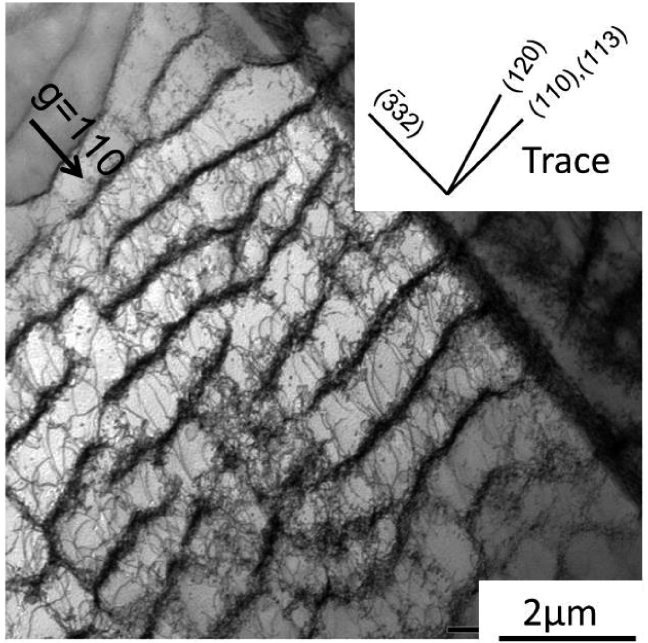

Fig. 10 Traces of slip planes. (110) trace is parallel to dislocation walls.

である7). fcc 金属では (100)Wall と (001)Wall の組み合わせで Labyrinth 組織が形成されることが知られている．Li らはこ れを，主すべり系と臨界すべり系の 2 つ転位のバーガース ベクトルを合成し，その合成べクトルに対して垂直な面に 沿って転位 Wall が形成されたと解釈した7)。この面は，2つ のバーガースベクトルの二等分面となり， Petrenec らは bcc 金属でもこの位置に転位Wallが形成されることを指摘した ${ }^{13)}$. 本研究において, 転位 Wall を構成するバーガースベクトルは $\mathbf{b}=a / 2[111]$ および $\mathbf{b}=a / 2[\overline{1} 11]$ であった。供試材は引張圧 縮変形を受けているため, 正負のバーガースベクトルをとも に考慮すれば，それらの合成べクトルは

$a / 2[111]+a / 2[\overline{1} \overline{1} 1]=a[001]$

$a / 2[111]+a / 2[11 \overline{1}]=a[110]$

の 2 通りとなる。この合成べクトルに垂直な転位Wall は (001) Wall および (110) Wall となり，本研究で観察した Labyrinth 組 織と一致する.

fcc 金属においては，主すべり系と臨界すべり系のバーガー スベクトルは直交するため，主すべり系と臨界すべり系が同 時に活動する条件では，Turenne らの解釈から予測される転 位 Wall の形成方位と， Li らの解釈から予測される転位 Wall の形成方位は一致する。しかし bcc 金属においては，2つの 活動すべり系の転位のバーガースベクトルが直交しないため, これらの予測は一致しない。ただし，bcc 金属においても主 すべり面と二次すべり面が同一になる場合，すなわち二次す ベり面が共面すべりの場合に限り，両者の予測は一致する. 
本研究においては，転位のバーガースベクトルの同定に留ま り, すべり面の同定には至っていない。 今後, 活動すべり系 を制御した試験を行い, Labyrinth 組織中の転位 Wall の形成 過程を明らかにしていく.また, 転位組織の三次元構造を卜 モグラフィや Electron Channeling Contrast 法を用いて観察 し, Labyrinth 組織中の転位 Wall の形成過程を明らかにする ことを予定している.

\section{5. 結言}

$\mathrm{Fe}-1$ mass\% Si 合金に対して低サイクル疲労試験を行い, 転位組織を超高圧電子顕微鏡で観察し，以下のことを明らか にした。

・転位組織は Cell 組織, Wall 組織, Vein 組織の混合組織で あった。

・転位 Wall は 2 種類のバーガースベクトルの転位で構成され ていた。

・Wall 組織は, (110)Wall と (001)Wall から成る Labyrinth 組 織である.

・Labyrinth 組織を構成する転位 Wall の面方位は, fcc 金属の Labyrinth 組織の形成機構を bcc 金属に拡張すれば，説明が可 能である.
本研究は文部科学省委託事業ナノテクノロジープラット フォーム課題として, 名古屋大学微細構造解析プラット フォームの支援を頂きました.

文献

1) T. Yokoi and M. Takahashi: J. Mater. Sci. 36(2001) 5757-5765.

2) H. Shuto and T. Yokoi: CAMP-ISIJ 28(2015) 261.

3) P. J. Woods: Philos. Mag. 28(1973) 155-191.

4) J. I. Dickson, J. Boutin and G. L'espérance: Acta Metall. 34(1986) 1505-1514.

5) C. Laird, Z. Wang, B. T. Ma and H. F. Chai: Mater. Sci. Eng. A 113 (1989) 245-257.

6) H. Mughrabi: Metall. Mater. Trans. A 40(2009) 1257-1279.

7) P. Li, S. X. Li, Z. G. Wang and Z. F. Zhang: Prog. Mater. Sci. 56 (2011) 328-377.

8) H. Mori, M. Tokuwame and T. Miyazaki: Philos. Mag. A 40(1979) 409-433.

9) S. E. Fielding and W. M. Stobbs: J. Microscopy 130(1983) 279288.

10) S. Turenne, G. L'espérance and J. I. Dickson: Acta Metall. 36 (1988) 459-468.

11) H. J. Roven and E. Nes: Scr. Metall. 21(1987) 1727-1732.

12) H. J. Roven and E. Nes: Acta Metall. Mater. 39(1991) 1719-1733.

13) M. Petrenec, J. Polák, K. Obrtlík and J. Man: Acta Mater. 54 (2006) 3429-3443.

14) K. Ushioda, M. Goto, Y. Komatsu, A. Hoshino and S. Takebayashi: Tetsu-to-Hagané 94(2008) 321-330. 